\title{
EFFECT OF CONTROL SYSTEMS ON BACTERIA COMMUNITY STRUCTURE IN SEQUENCING BATCH BIOFILM REACTORS TO TREAT WASTEWATER
}

\author{
JIN, Y. $.^{*}-\mathrm{WU}, \mathrm{C} .^{2}$ \\ ${ }^{1}$ Department of Civil Engineering, Luoyang Institute of Science and Technology, Luoyang \\ 471023, China \\ ${ }^{2}$ Department of Environmental Engineering and Chemistry, Luoyang Institute of Science and \\ Technology, Luoyang 471023, China \\ (e-mail:ch_wu70l@163.com; phone:+86-188-3883-2915) \\ *Corresponding author \\ e-mail: jyx9988@126.com; phone: +86-135-2595-4418 \\ (Received 27 $7^{\text {th }}$ Feb 2019; accepted $3^{\text {rd }}$ May 2019)
}

\begin{abstract}
This study aimed to evaluate the effect of control systems, including an intelligent control system (ICS) and a conventional timer control system (TCS), on bacteria community structure. Clone library methods for $16 \mathrm{~S}$ rDNA were used in sequencing batch biofilm reactors (SBBRs) to treat wastewater. A total of 108 clones were randomly selected and individually sequenced from 16S rDNA libraries. Results indicated that the community structure was different in each SBBR under different controlled systems. The dominant bacterial communities and their contents showed significant differences. The dominant bacterial community Bacteroidetes has a proportion of $45 \%$, whereas $\beta$ proteobacteria has $37 \%$. The significant difference in the performance of nitrogen and phosphorus removal in ICS from TCS was the dominant bacterial community.
\end{abstract}

Keywords: intelligent control system (ICS), sequencing batch biofilm reactor (SBBR), 16S rDNA library, bacterial community, denitrification

\section{Introduction}

The most fundamental method for controlling water eutrophication and preventing water pollution is to treat pollution sources and control pollutant emissions. This approach will enable the nitrogen and phosphorus obtained from the wastewater treatment plants to meet emission standards (Zou et al., 2006). The wastewater discharge standard at present is increasingly becoming strict in all countries around the world. Many new and original wastewater treatment plants are facing the pressure of standard nitrogen and phosphorus emissions (Mielcarek et al., 2015; Ge, 2010; Wen et al., 2015).

Sequencing batch biofilm reactor (SBBR) is novel of composite biofilm reactor and a new technology for nitrogen and phosphorus removal that is being studied by scholars at home and abroad. SBBR utilizes time sequence. Construction cost is low because biological reaction proceeds in a single tank without physical partition (Yang et al., 2014). Given a large amount of biomass, the reactor can resist shock load (Goh et al., 2009; Fu et al., 2018). Sludge bulking is not a problem because of low sludge

Production (Amulya et al., 2015; Zhao et al., 2017) SBBR has been used in the research of nitrogen and phosphorus removal from urban wastewater (Choi et al., 2008; Zhang et al., 2009; Fu et al., 2010; Hosseini et al., 2012). Microorganisms in SBBR are attached to the carrier to form a biofilm with long sludge age and food chain. The 
biofilm has certain thickness. Under aerobic conditions, the biofilm creates a hypoxic microenvironment where nitrification and denitrification can occur simultaneously; this condition leads to high nitrogen removal efficiency (Isanta et al., 2015). Changing the operating conditions of the reactor will change the environment where microorganisms depend on for survival, as well as the bacterial community structure of microorganisms, thus leading to the change of nitrogen and phosphorus removal efficiency (Aydin et al., 2015). Therefore, the present study on the effect of control systems on the bacterial community structure in SBBR system is important to optimize the bacterial community structure and improve the efficiency of nitrogen and phosphorus removal.

The 16S rDNA clone library method is used to amplify and analyze the full-length sequence of $16 \mathrm{~S}$ rDNA to analyze the bacterial community structure in the environmental samples (Cantafio et al., 1996; Sanapareddy et al., 2009; Yu et al., 2010). Given its high speed, accuracy, good repeatability, and abundant information, this method has become the main approach used in the research of bacterial community structure and diversity in wastewater treatment systems. In the present paper, two SBBRs under different control systems were adopted to treat urban wastewater. SBBR under an intelligent control system (ICS) controls the process of wastewater treatment based on DO and temperature. By contrast, SBBR under a timer control system (TCS) changes the operation conditions based on time setting. The 16S rDNA clone library method was adopted to study the similarities and differences of the bacterial community structures of these two reaction systems and to determine the dominant bacterial communities. This approach identifies the effect of control systems on the bacterial community structure of the system.

\section{Materials and methods}

\section{SBBRs configurations and operational conditions}

Experiments were conducted in two SBBRs controlled by an ICS and a TCS. Figure 1 shows that the acrylic reactors were composed of polymethyl methacryate with a capacity of $30 \mathrm{~L}$ and a working volume of $20 \mathrm{~L}$. Two SBBRs and operations conditions were described in an earlier publication (Jin et al., 2012).

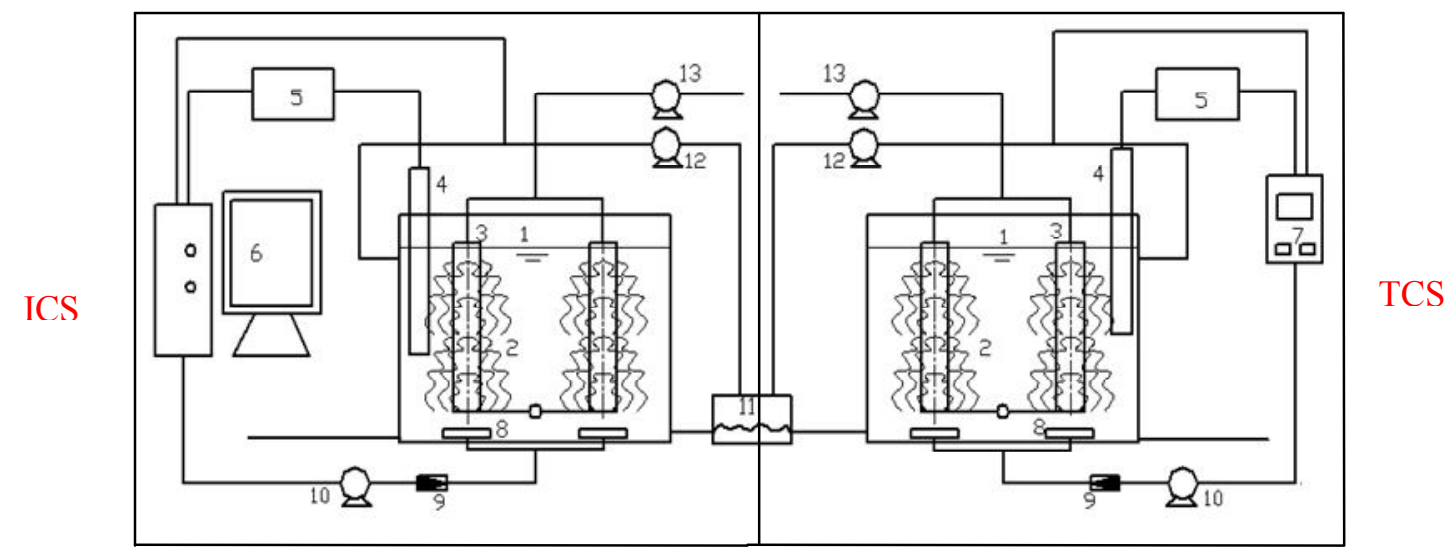

Figure 1. Schematic of two SBBRs. 1. Bioreactor. 2. Fiber threads carrier. 3. Cylinder. 4. DO sensor. 5. DO detector. 6. Computer. 7. Timer. 8. Porous stones. 9. Rotameter. 10. Air compressor. 11. Thermostatic bash. 12. Circulation pump. 13. Drawn pump 


\section{Synthetic wastewater}

Synthetic wastewater was used as feed to evaluate SBBR performance. Wastewater was prepared based on the characteristics of Chinese municipal wastewater with the following composition (concentrations in mg/L): glucose $\left(\mathrm{C}_{6} \mathrm{H}_{12} \mathrm{O}_{6}\right)(332) ; \mathrm{NH}_{4} \mathrm{Cl}(213$ at $\mathrm{C} / \mathrm{N}$ ratio of around 5.0) $1 ; \mathrm{KH}_{2} \mathrm{PO}_{4}$ (21.95); $\mathrm{ZnCl}_{2}(50), \mathrm{MgSO}_{4}$ (50); and a $1 \mathrm{ml}$ trace element mixture consisting of $\mathrm{CaCl}_{2}, \mathrm{CuCl}_{2}, \mathrm{NiCl}_{2}, \mathrm{FeSO}_{4}$ and $\mathrm{H}_{3} \mathrm{BO}_{3} . \mathrm{NaHCO}_{3}$ measuring $100 \mathrm{mg} / \mathrm{L}$ was used to maintain the $\mathrm{pH}$ of the wastewater at 6.8 to 7.2. Synthetic wastewater is characterized in Table 1. All chemicals and reagents were of analytical grade.

Table 1. Characteristics of synthetic wastewater during stable operation

\begin{tabular}{c|c|c|c|c|c}
\hline Parameter & $\mathrm{COD}(\mathrm{mg} / \mathrm{L})$ & $\mathrm{NH}_{4}{ }^{+}-\mathrm{N}(\mathrm{mg} / \mathrm{L})$ & $\mathrm{TN}(\mathrm{mg} / \mathrm{L})$ & $\mathrm{TP}(\mathrm{mg} / \mathrm{L})$ & $\mathrm{pH}$ \\
\hline Values & $326 \pm 30$ & $61 \pm 10$ & $65+10$ & $5 \pm 1$ & $7 \pm 0.2$ \\
\hline
\end{tabular}

\section{Experimental methods}

\section{Sample collection and DNA extraction}

After about five weeks of domestication, the biofilm was successfully cultured in two reactors before being entered into the operating period. Through 30 days of sample analysis, the results showed that the reaction period was $6 \mathrm{~h}$ for ICS and $9 \mathrm{~h}$ for TCS. The operation results of a cycle were extracted as the example. The concentrations of COD, TN, $\mathrm{NH}_{4}{ }^{+}-\mathrm{N}$, and TP in inflow water were 309.5, 63.61, 60.28, and $5.16 \mathrm{mg} / \mathrm{L}$, respectively. The removal rates of $\mathrm{COD}, \mathrm{TN}, \mathrm{NH}_{4}{ }^{+}-\mathrm{N}$, and $\mathrm{TP}$ were 93.4\%, 85.6\%, $100 \%$, and $100 \%$ in ICS and $91.1 \%, 70.9 \%, 100 \%$, and $100 \%$ in TCS, respectively. Thus, TN removal rate in ICS was $14.7 \%$ higher than that in TCS.

Bacteria Sampling of the two reactors obtained according to the method of Hao et al. (2009). During the stable operation of two SBBRs, the biofilm samples were taken with sterile scissors and sterile brush from the fillers at different vertical depths and horizontal positions in the SBBRs under ICS and TCS. The samples were dissolved in $500 \mathrm{~mL}$ distilled water and fully shaken. The supernatants were removed after precipitation for $30 \mathrm{~min}$. Then, $40 \mathrm{~mL}$ of the solutions was taken from the precipitation layers and placed in $50 \mathrm{~mL}$ centrifuge tubes. After $3 \mathrm{~min}$ of centrifugal separation (5147R centrifuge, Germany, Eppdorf) at the rate of $1000 \mathrm{r} / \mathrm{min}, 30 \mathrm{~mL}$ of sterile TE buffers $\left(10 \mathrm{mmol} / \mathrm{L}\right.$, Tris-HCl, $1 \mathrm{mmol}$ EDTA, adjusted to $\mathrm{pH}=8,121{ }^{\circ} \mathrm{C}$ and sterilized for $20 \mathrm{~min}$ ) was added in the solutions. The supernatants were removed after recentrifugation. Then, $15 \mathrm{~mL}$ of distilled water was added and fully shaken. Afterward, $5 \mathrm{~mL}$ of solution was taken for DNA extraction in the biofilms. The pretreated water samples were filtered $(0.22 \mu \mathrm{m}$ bacterial filter film). The filter films were soaked in $10 \mathrm{~mL}$ of sterilized saline water after filtration and then placed in an ultrasonic cleaning instrument (KH2200DB, Kunshan Hechuang in China) and shaken for $10 \mathrm{~min}$. The solutions were then repeatedly beaten by the liquid drawing gun to enable the cells on the membrane to enter completely into the solutions. The solutions were placed in centrifuge tubes $(1.5 \mathrm{~mL})$ and underwent centrifugation for $3 \mathrm{~min}$ at the rate of $10000 \mathrm{r} / \mathrm{min}$ to facilitate bacteria collection. The metagenomics DNA extraction kits produced by Shanghai Sangon were adopted to extract ICS samples and TCS samples. 


\section{S rDNA gene full-length amplification and carrier connection transformation}

Bacteria 16S rDNA universal primer 27F (5'-AGAGTTTGATCCTGGCTCAG-3', $\mathrm{M}=\mathrm{CorA}$ ) and 1492R (5'-CTACGGCTACCTTGTTACGA-3', T = 3', Y = CorT) were adopted to amplify the target genes of two groups of samples (Masoud et al., 2011). The PCR reaction procedure (Hao et al., 2009) was predegenerated at $95{ }^{\circ} \mathrm{C}$ for $5 \mathrm{~min}$, degenerated at $94{ }^{\circ} \mathrm{C}$ for $30 \mathrm{~s}$; annealed at $52{ }^{\circ} \mathrm{C}$ for $30 \mathrm{~s}$, and extended to $72{ }^{\circ} \mathrm{C}$ for $2 \mathrm{~min}$ for a total of 35 circulations. The procedure also involved extension at $72{ }^{\circ} \mathrm{C}$ for 10 min before preservation at $4{ }^{\circ} \mathrm{C}$. PCR amplification products were detected by $1.2 \%$ agarose gel electrophoresis. The products were connected to PGEM-T clone by PGEM$\mathrm{T}$ cloning (Promage Company) kits and heat-shock transformed into escherichia coli DH5 $\alpha$ competent cells. The products were then coated with Amp/IPTG-Gal that contains LB culture mediums. After $16 \mathrm{~h}$ of culture at $37^{\circ} \mathrm{C}$, the samples were subjected to $4{ }^{\circ} \mathrm{C}$ color development process for $1 \mathrm{~h}$. White-blue plaque selection and white plaque validation were conducted. The positive clones in each sample were randomly selected for sequencing by Shanghai Sangon Co., Ltd.

\section{System development analysis}

Chimera detection was conducted on the sequences using a Chimera detection program on the Ribosomal database project (RDP) website. The obtained sequences were then classified by Dutor software, and similar sequences were excluded. The remaining sequences were entered into the BLAST facility of the National Center for Biotechnology Information (http://www.ncbi.nlm.nih.gov). Comparative analysis was conducted on the remaining sequences and those existing in GenBank + EMBL + DDBJ + PDB. Sequences with the highest similarity and those with species that have high similarity were downloaded as reference. All sequences were compared by ClustalW program in BioEdit. The system development tree diagram was generated using MEGA 4.0.

\section{Results and discussion}

\section{Bacterial diversity analysis of samples in ICS and TCS}

The sequences were analyzed with Dutor software. After eliminating similar sequences, ICS obtained 30 genotypes and 32 for TCS. The sequence of each genotype in ICS and TCS was entered into the RDP website. The sample system group was determined by a classifier program. After analysis, 16S rDNA sequences of 108 positive clones of bacteria were identified in the ICS sample library, which belonged to 7 bacterial communities (as shown in Figs. 2 and 3). These sequences are Bacteroidetes $(45 \%), \beta$-proteobacteria (27\%), $\gamma$-proteobacteria (16\%), $\alpha$-proteobacteria (3\%), Verrucomicrobia (3\%), Chloroflexi (3\%), and unclassified_Proteobacteria (3\%). The dominant bacterial communities were Bacteroidetes (45\%), $\beta$-proteobacteria $(27 \%)$, and $\gamma$-proteobacteria $(16 \%)$. The $16 \mathrm{~S}$ rDNA sequences of 108 positive clones of bacteria in TCS sample library belonged to 9 bacterial communities (as shown in Figs. 4 and 5), namely, $\beta$-proteobacteria (37\%), $\gamma$-proteobacteria (25\%), Bacteroidetes $(24 \%)$, $\delta$-proteobacteria (3\%), Firmicutes (3\%), Nitrospira (3\%), Actinobacteria (3\%), Acidobacteria (3\%), and unclassified_Proteobacteria (5\%). The dominant bacterial communities in ICS were Bacteroidetes, $\beta$-proteobacteria, and $\gamma$-proteobacteria, which account for $45 \%, 27 \%$, and $16 \%$, respectively. The dominant bacterial communities in 
TCS were $\beta$-proteobacteria, $\gamma$-proteobacteria, and Bacteroidetes, accounting 37\%, 25\%, and $24 \%$, respectively. Different operation modes and different growth environments for microorganism between ICS and TCS led to different dominant bacterial communities and different community structures. In ICS, the growth environment for biofilm microorganisms was (aerobic/hypoxic) ${ }^{\mathrm{n}}$. Bacteroidetes was the dominant bacterial community, which has a proportion of $45 \%$. In TCS, the growth environment for biofilm microorganisms was anaerobic/aerobic, in which $\beta$-proteobacteria was the dominant bacterial community with a proportion of $37 \%$. The community structure of ICS was more stable than that of TCS, and the communities in ICS were less than those in TCS.

\section{System development analysis of bacteria in samples in ICS and TCS}

To further understand the system development of bacteria in biofilm samples in ICS and TCS, the genotypes that represent different sequences were ordered in accordance with the principle of maximum homology. This approach was adopted to construct the system development tree diagrams of Proteobacteria and other communities in ICS and TCS gene libraries, as shown in Figures 4, 5, 6, and 7. Figures 4 and 5 show the system development trees of Proteobacteria and other communities based on 16S rDNA sequence in ICS system. Figures 6 and 7 show the system development trees of Proteobacteria and other communities based on 16S rDNA sequence in ICS system.

\section{System development analysis of bacterial in ICS}

In ICS, Bacteroidetes was the dominant community with a proportion of $45 \%$. This finding means that nearly half of bacteria in the biofilm samples in ICS were Bacteroidetes. The most similar structure of this sequence is from eutrophic lakes (Cantafio et al., 1996), which include 12 genotypes of uncultured bacteria. The bacteria in Bacteroidetes community were bacillus of different sizes. These bacteria were reported only in the phosphorus removal system, but were barely investigated in the activated sludge and nitrogen removal system (Amann et al., 1995). ICS did not adopt anaerobic phosphorus release, but it showed significant phosphorus removal effect. Moreover, the performance of ICS in TN removal was obviously better than that of TCS. Thus, we can conclude the presence of microorganisms with functions of anoxic phosphorus uptake and denitrifying phosphorus removal, which exist in the form of polyphosphate under the aerobic condition in Bacteroidetes (Liu et al., 1996). Therefore, new bacteria exist that are related to nitrogen and phosphorus removal in Bacteroidetes. These bacteria accounted for $27 \%$ of bacteria in the library, including 9 genotypes. The homology between Z-28 and Thauera sp. (CP001281) was as high as $99 \%$. Thauera $s p$. was the denitrification bacterium that could remove $\mathrm{NO}_{3}^{-}-\mathrm{N}$ and $\mathrm{PO}_{4}{ }^{3-}-\mathrm{P}$ from wastewater through denitrification (Manz et al., 1994; Amann et al., 1995). This bacterium played a very important role in denitrification and in the degradation process of organic matters (Ayara et al., 2011). In the anoxic or aerobic period, the exterior of the biofilm was the aerobic layer and the interior was the special structure for the anaerobic/anoxic layer. This structure provided favorable conditions for the existence of denitrifying bacteria and benefited nitrogen removal or denitrifying phosphorus removal in ICS. The other clones were uncultured bacteria. The $\gamma$ proteobacteria was the third largest bacterial community with the proportion of $16 \%$ in the library. This bacterium included three genotypes, among which the homology 
between Z-15 and Xanthomonas sp. (AJ786786) was 98\%. Xanthomonas sp. had strong degradation ability for organic carbon. Thus, it was beneficial for COD removal.

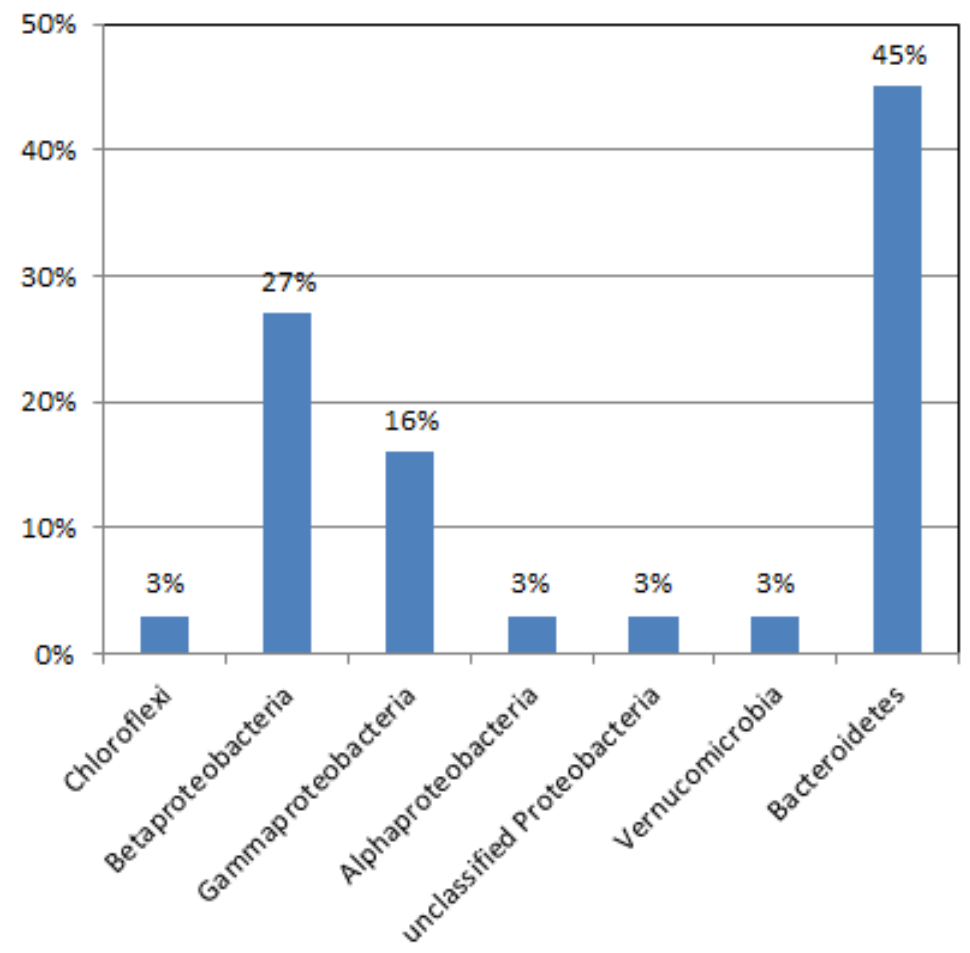

Figure 2. Proportion of phyla in the clone library from ICS

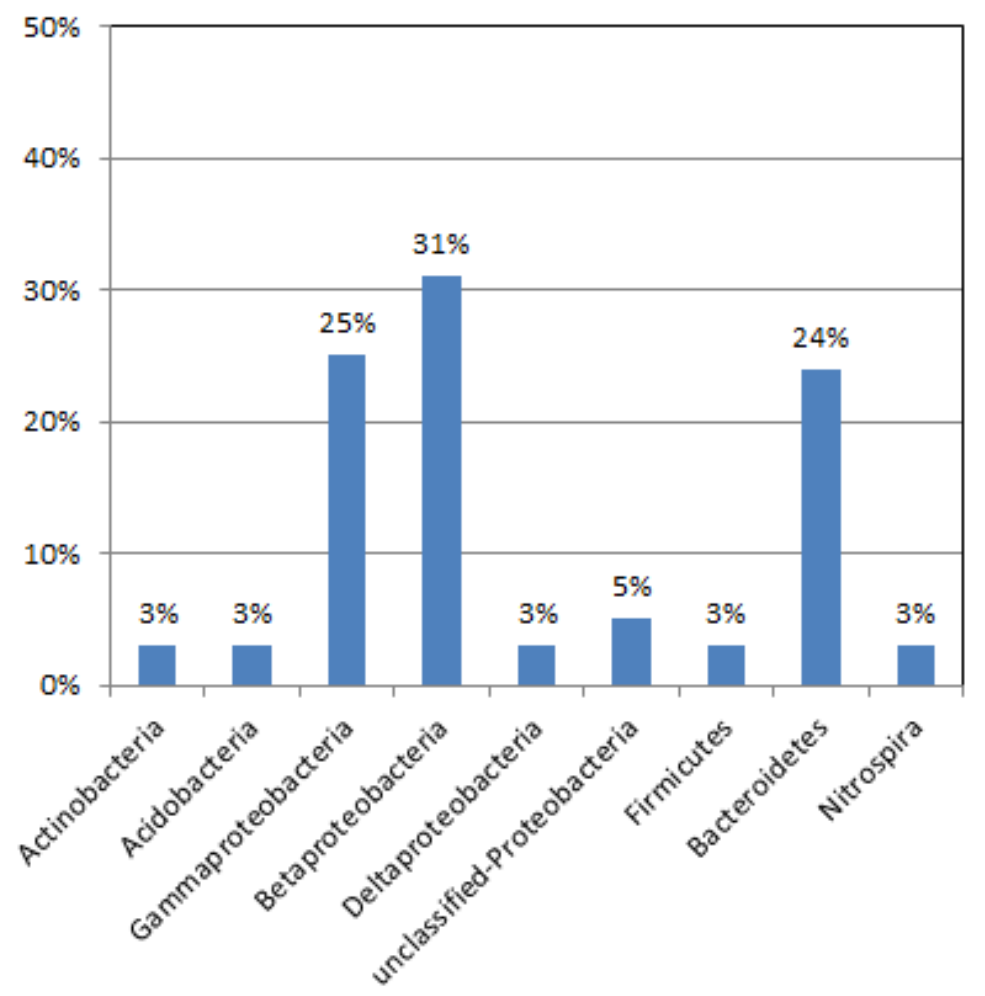

Figure 3. Proportion of phyla in the clone library from TCS

APPLIED ECOLOGY AND ENVIRONMENTAL RESEARCH 17(4): 7549-7559. http://www.aloki.hu • ISSN 15891623 (Print) • ISSN 17850037 (Online) DOI: http://dx.doi.org/10.15666/aeer/1704_75497559 (c) 2019, ALÖKI Kft., Budapest, Hungary 


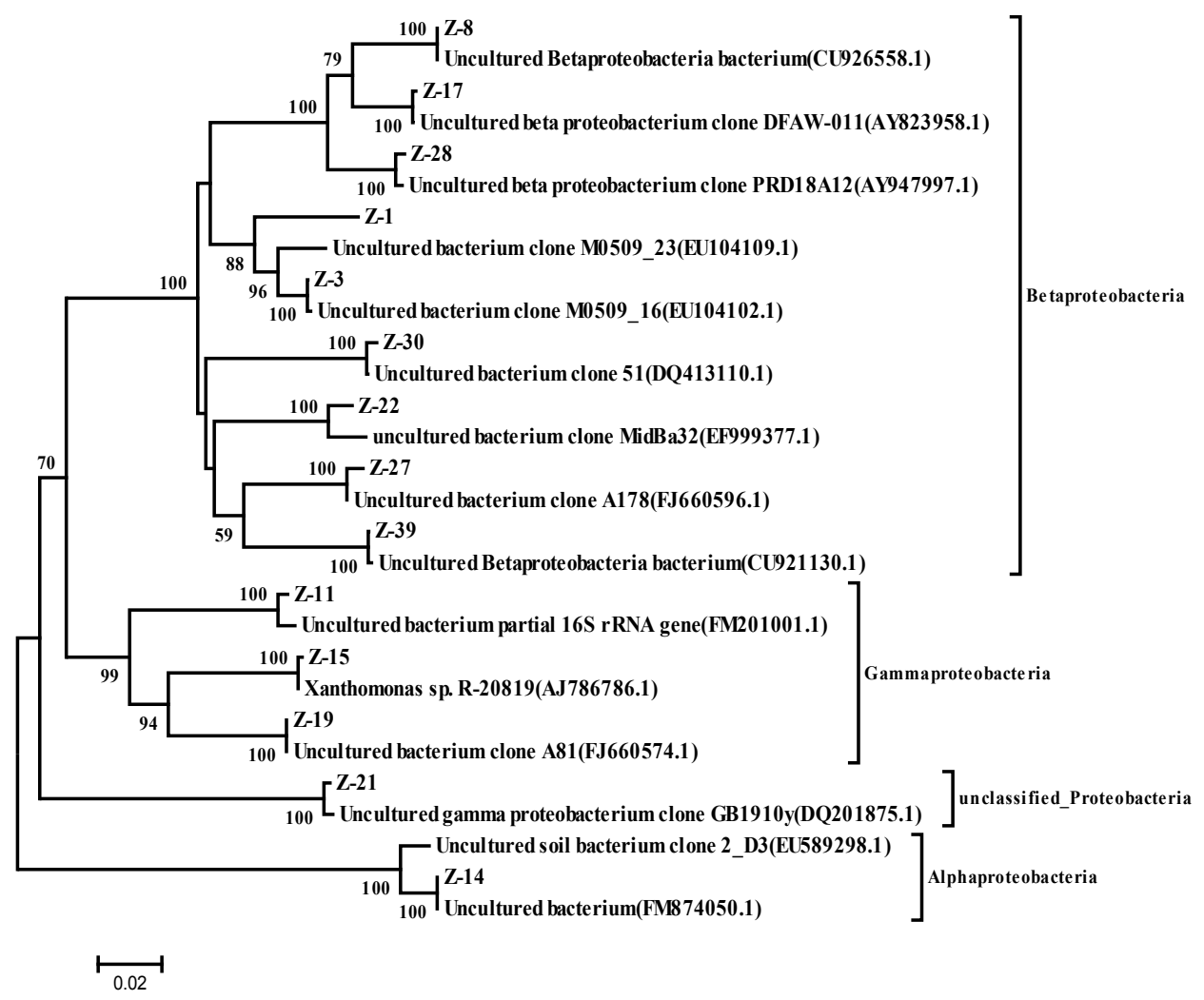

Figure 4. Phylogenetic tree of proteobacteria isolated from ICS column based on $16 S$ rDNA sequences

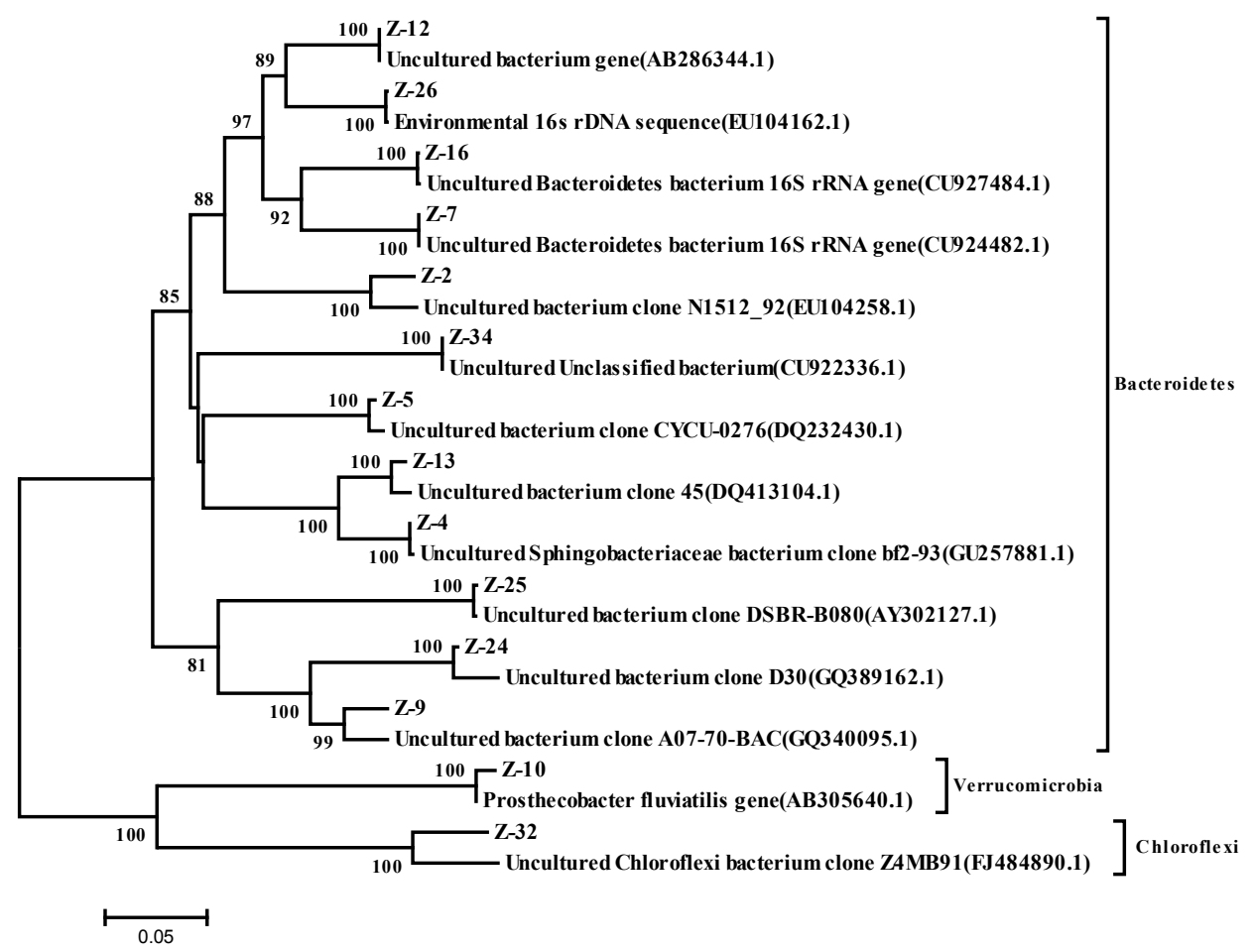

Figure 5. Phylogenetic tree of other bacteriophyta isolated from ICS column based on $16 S$ rDNA sequences 


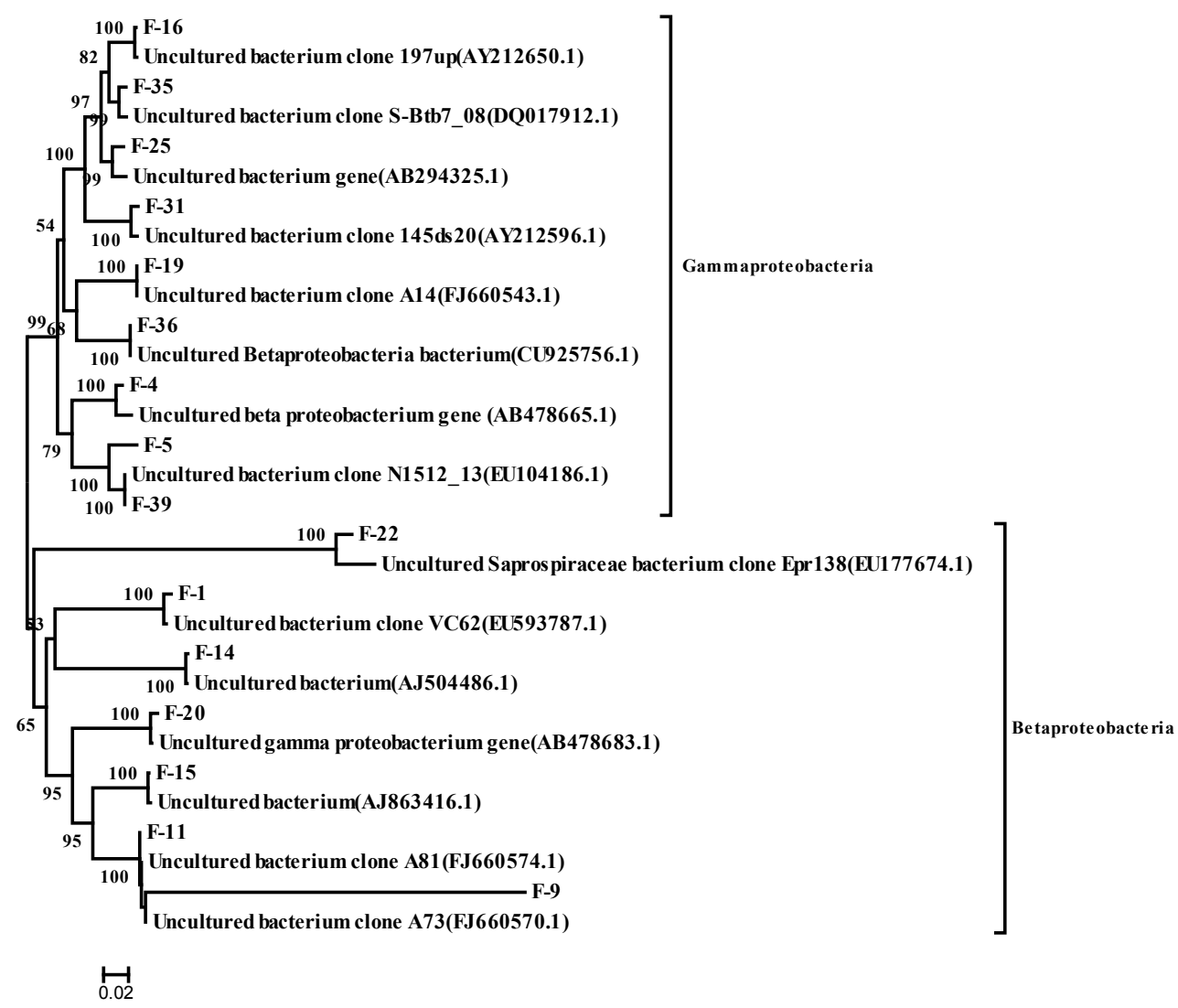

Figure 6. Phylogenetic tree of proteobacteria isolated from TCS column based on $16 S$ rDNA sequences

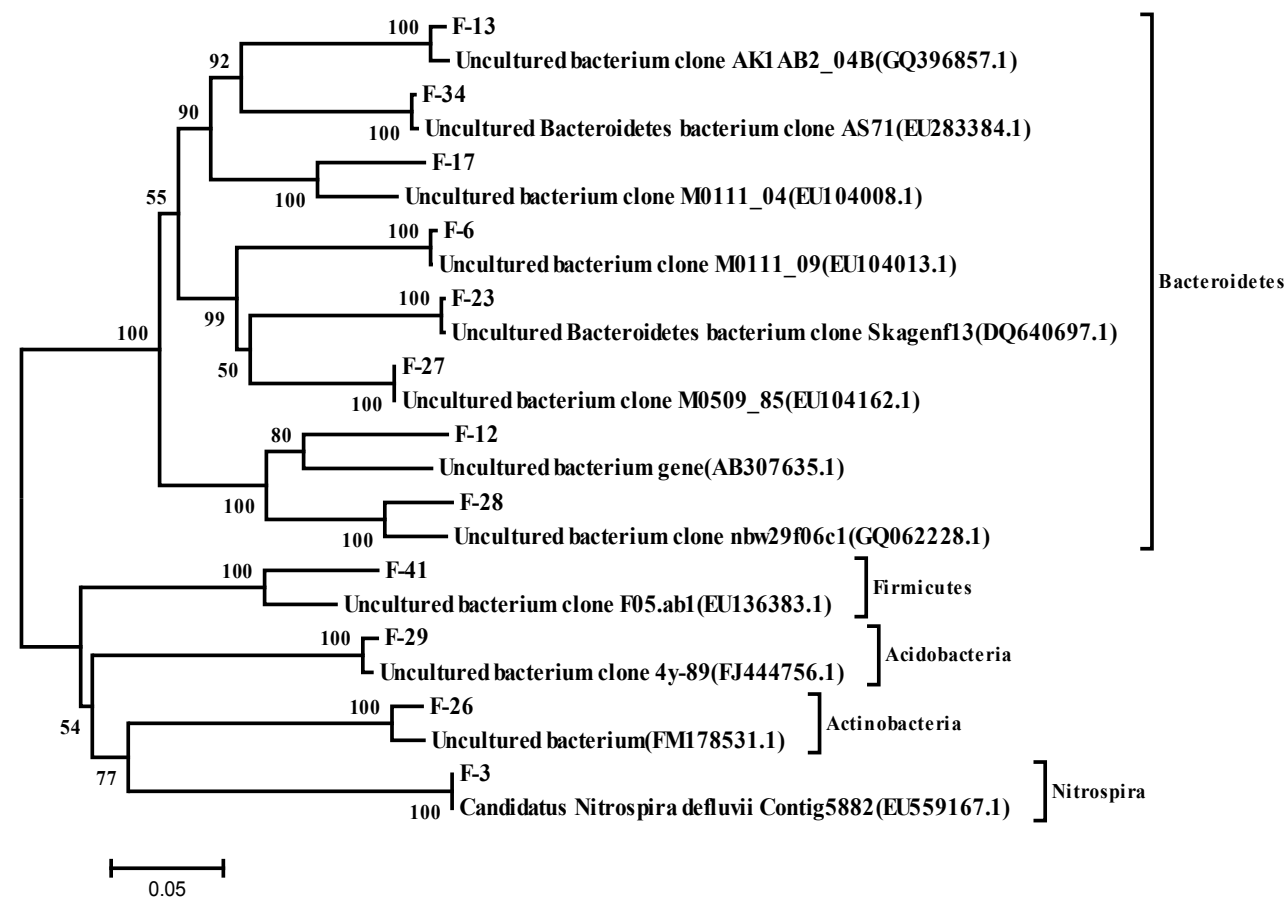

Figure 7. Phylogenetic tree of other bacteriophyta isolated from ICS column based on 165 rDNA sequences 


\section{System development analysis of bacterial in TCS}

In TCS, $\beta$-proteobacteria was the dominant bacterial community with proportion of $37 \%$. However, it was the second largest bacterium in ICS with proportion of $27 \%$. This bacterium included 12 genotypes, in which the homology between F-2 and Bacterium AEOC009 (AB208727) was 99\% and that between F-42 and Arabidopsis lyrata was 99\%. Other clones were uncultured bacteria. According to Amann et al.'s study of the bacterial community structure in the biological reactor, $\beta$-proteobacteria and Bacteroidetes were the most dominant communities in the wastewater treatment system. The former played an important role in organic matter degradation, nitrogen and phosphorus removal, and flocculation structure formation (Burrell et al., 1999). Second, $\gamma$-proteobacteria, $\delta$-proteobacteria, and unclassified Proteobacteria accounted for $25 \%$, $3 \%$, and $5.5 \%$ of bacteria in the library, respectively. They were all Proteobacteria, which could efficiently remove organic matters, nitrogen, and phosphorus. Bacteroidetes was the third largest community in the library with proportion of $24 \%$, but it was the dominant community in ICS. The bacteria in this community were related to nitrogen and phosphorus removal. Thus, ICS had better performance than TCS in nitrogen and phosphorus removal. Nitrospira (nitrification spirillum) accounted for 3\% of bacteria in the library. The homology among F-3 and other two unnamed Nitrospira (EU55916 and DQ059545) was 99\%. Nitrospira was an important $\mathrm{NO}_{2}-\mathrm{N}$ oxidation bacterium. The research of Burrell et al. (1999), Lee et al. (2002) and Benítez-Páez et al. (2016) showed that the bacteria in Nitrospira species could have played the role of $\mathrm{NO}_{2}{ }^{-}$ $-\mathrm{N}$ oxidation during nitrification rather than nitrobacter.

\section{Conclusions}

(1) The concentrations of COD, TN, NH4 + - N, and TP in inflow water were 309.5, $63.61,60.28$, and $5.16 \mathrm{mg} / \mathrm{L}$, respectively. The removal rates of COD, TN, NH4 + -N, and TP were $93.4 \%, 85.6 \%, 100 \%$, and $100 \%$ in ICS and $91.1 \%, 70.9 \%, 100 \%$, and $100 \%$ in TCS, respectively. Thus, TN removal rate in ICS was $14.7 \%$ higher than that in TCS.

(2) Different control systems of SBBR will cause differences in bacterial community structures and their relative proportions. In the ICS sample library, 16S rDNA sequences by bacterial clones belonged to 7 bacterial communities, namely, Bacteroidetes, $\beta$-proteobacteria, $\gamma$-proteobacteria, $\alpha$-proteobacteria, Verrucomicrobia, Chloroflexi, and unclassified_Proteobacteria. In the TCS sample library, 16S rDNA sequences by bacterial clones belonged to 9 bacterial communities, namely, $\beta$ proteobacteria, $\gamma$-proteobacteria, Bacteroidetes, $\delta$-proteobacteria, Firmicutes, Nitrospira, Actinobacteria, Acidobacteria, and unclassified_Proteobacteria.

(3) The growth environment of the biofilm microorganisms in ICS was aerobic/hypoxic, in which Bacteroidetes was the dominant community with the proportion of $45 \%$. The growth environment of the biofilm microorganisms in TCS was anaerobic/aerobic, in which Betaproteobacteria was the dominant community with the proportion of $37 \%$.

Acknowledgements. This study was supported by the key scientific and technological project of Henan Province (172102310730 and 172102310736), and Henan Province Key research projects of higher education institutions (17A610011). 


\section{REFERENCES}

[1] Amann, R. I., Ludwig, W., Schleifer, K. H. (1995): Phylogenetic identification and in situ detection of individual microbial cells without cultivation. - Fems Microbiology Reviews 59(1): 143-69.

[2] Amulya, K., Jukuri, S., Mohan, S. V. (2015): Sustainable multistage process for enhanced productivity of bioplastics from waste remediation through aerobic dynamic feeding strategy: Process integration for up-scaling. - Bioresource Technology 188: 231-240.

[3] Ayara, J. M., Erijman, L. (2011): Balance of neutral and deterministic components in the dynamics of activated sludge floc assembly. - Microbial Ecology 61: 486-492.

[4] Aydin, S., Ince, B., Ince, O. (2015): Development of antibiotic resistance genes in microbial communities during long-term operation of anaerobic reactors in the treatment of pharmaceutical wastewater. - Water Research 83: 337-345.

[5] Benítez-Páez A., Portune K. J., Sanz Y. (2016): Species-level resolution of 16S rRNA gene amplicons sequenced through the MinIONTM portable nanopore sequencer. GigaScience 5: 4-11.

[6] Burrell, H. P., Keller, J., Blackall, L. (1999): Characterisation of the bacterial consortium involved in nitrite oxidation in activated sludge. - Water Sci. Technol. 39: 45-53.

[7] Cantafio, A. W., Hagen, K. D., Lewis, G. E. (1996): Pilot-scalese-lenium bioremediation of San Joaquin drainage water with Thauera selenatis. - Applied and Environmental Microbiology 62(9): 3298-303.

[8] Choi, H. J., Lee, S. M., Choi, C. H., Kwon, M. C., Lee, H. Y. (2008): Influence of the wastewater composition on denitrification and biological p-removal in the SDN-Pprocess (b) Effect of acetate. - Journal of Hazardous Materials 158: 151-160.

[9] Fu, B., Liao, X. Y., Ding, L. L., Ren, H. Q. (2010): Characterization of microbial community in an aerobic moving bed biofilm reactor applied for simultaneous nitrification and denitrification. - World J. Microbiol. Biotechnol. 26: 1981-1990.

[10] Fu, K., Fu, Ch., Wang, H., Su, X., Li, Hui 1, Qiu, F., Cao, X. Q. (2018): Effects of nitrite on nitrogen removal performance and $\mathrm{N}_{2} \mathrm{O}$ emission in a biofilm CANON process. Chinese Journal of Environmental Engineering 12: 2776-2782.

[11] Ge, S. J., Peng, Y. Z., Wang, S. Y., Guo, J. H., Ma, B., Zhang, L. A., Cao, X. (2010): Enhanced nutrient removal in a modified step feed process treating municipal wastewater with different inflow distribution ratios and nutrient ratios. - Bioresour Technol. 101: 9012-9019.

[12] Goh, C. P., Seng, C. E., Sujari, A., Lim, P. E. (2009): Performance of sequencing batch biofilm and sequencing batch reactors in simultaneous p-nitrophenol and nitrogen removal. - Environmental Technology 30: 725-733.

[13] Hao, C. B., Wang, G. C., Dong, J. N., Zhang, Q., Cai, W. T. (2009): Bacterial Biodiversity in the Groundwater Contaminated by Oil. - Environmental Science 8: 24642472.

[14] Hosseini, K. E., Alavi, M. R., Hashemi, S. H. (2012): Investigation of decolorization kinetics and biodegradation of azo dye Acid Red 18 using sequential process of anaerobic sequencing batch reactor/moving bed sequencing batch biofilm reactor. - International Biodeterioration \& Biodegradation. 71: 43-51.

[15] Isanta, E., Reino, C., Caarera, J. (2015): Stable partial nitritation for low-strength wastewater at low temperature in an aerobic granular reactor. - Water Research 80: 149158.

[16] Jin, Y. X., Ding, D. H., Feng, C. P., Tong, S., Suemura, T., Zhang, F. (2012): Performance of sequencing batch biofilm reactors with different control systems in treating synthetic municipal wastewater. - Bioresource Technology 104: 12-19.

[17] Kim, T. S., Jeong, J. Y., Wells, G. F., Park, H. D. (2013): General and rare bacterial taxa demonstrating different temporal dynamic patterns in an activated sludge bioreactor. Applied and Environmental Microbiology 97: 1755-1763. 
[18] Lee, S., Lee, J., Lee, J. (2002): Molecular characterization of microbial community in nitrate-removing activated sludge. - Fems Microbiology Reviews 41: 85-93.

[19] Liu, B. B., Zhang, F., Feng, X. X. (2006): Thauera and Azoarcus as functionally important genera in a denitrifying quinoline-removal bioreactor as revealed by microbial community structure comparison. - FEMS Microbiology Ecology 55(2): 274-86.

[20] Manz, W., Wagner, M., Amann, R. (1994): Characterization of the microbial consortia active in two wastewater treatment plants. - Water Research 28: 1715-1723.

[21] Masoud, W., Takamiya, M., Vogensen, F. K., Lillevang, S. (2011): Characterization of bacterial populations in Danish raw milk cheeses made with different starter cultures by denaturating gradient gel electrophoresis and pyrosequencing. - International Dairy Journal 21: 142-148.

[22] Mielcarek, A., Rodziewicz, J., Janczukowicz, W., Thornton, A. J., Jóźwiak, T., Szymczyk, P. (2015): Effect of the C:N:P ratio on the denitrifying dephosphatation in a sequencing batch biofilm reactor (SBBR). - Journal of Environmental Sciences 4: 1-7.

[23] Sanapareddy, N., Hamp, T. J., Gonzalez, L. C., Hilger, H. A., Fodora. A., Clinton, S. M. (2009): Molecular Diversity of a North Carolina Wastewater Treatment Plant as by Pyrosequencing. - Applied and Environmental Microbiology 75: 1688-690.

[24] Wen, Y., Jin, Y. X., Wang, J. Y., Cai, L. P. (2015): MiSeq sequencing analysis of bacterial community structures in wastewater treatment plants. - Polish Journal of Environmental Studies 24: 1809-1815.

[25] Yang, K., Ji, B., Wang, H., Zhang, H., Zhang, Q. (2014): Bio-augmentation as a tool for improving the modified sequencing batch biofilm reactor. - Journal of Bioscience and Bioengineering 117: 763-771.

[26] Yu, F. B., Li, S. W., Guan, L. B., Li, S. P., Zhou, S. (2010): Bioaugmentation of a sequencing batch reactor with Pseudomonas putida ONBA-17, and its impact on reactor bacterial communities. - Journal of Hazardous Materials 176: 20-31.

[27] Zhang, L. Q., Wei, C. H., Zhang, K. F., Zhang, C. S., Fang, Q., Li, S. G. (2009): Effects of temperature on simultaneous nitrification and denitrification via nitrite in a sequencing batch biofilm reactor. - Bioprocess Biosystems Engineering 32: 175-182.

[28] Zhao, X. Y., Bian, W., Hou, A. Y. (2017): Characteristics of microbial community structure in the stable operation of the partial cut nitrification system with seasonal temperature. - China Environmental Science 4: 1366-1374.

[29] Zou, H., Du, G., Ruan, W., Chen, J. (2006): Role of nitrate in biological phosphorus removal in a sequencing batch reactor. - World J. Microbiol. Biotechnol. 22: 701-710. 